\title{
Can bowel necrosis be predicted with inflammatory markers in incarcerated inguinal hernia?
}

\section{Inflamatuar belirteçler Inkarsere inguinal hernilerde barsak nekrozunu öngörebilir mi?}

\author{
Tezcan AKIN ${ }^{1 *} \square$, Sabri OZDEN $\square$, Birkan BIRBEN'回, Yasin Orhan ERKUS' $⿴$ Bulent Cavit YUKSEL' $\square$ \\ Deniz TIKICI$^{3} \square$, Huseyin BERKEM ${ }^{1} \square$ Merve AKIN' $\square$, Sadettin ER' $\square$
}

'Ankara City Hospital, Department of General Surgery, Ankara/TURKEY

${ }^{2}$ Konya City Hospital, Department of General Surgery, Konya/TURKEY

${ }^{3}$ Mersin University, Faculty of Medicine, Department of Gastrointestinal Surgery, Mersin/TURKEY

\begin{abstract}
Aim: To evaluate the predictive or diagnostic value of inflammatory markers in the presence of bowel necrosis in patients with an incarcerated inguinal hernia.

Material and Methods: The sample consisted of 246 patients that were admitted to the Emergency Service of Ankara Numune Training and Research Hospital and were operated on between January 2013 and January 2018 with a diagnosis of incarcerated inguinal hernia $(\mathrm{IIH})$. The electronic patient records were screened to obtain the blood test results pertaining to lymphocyte count, neutrophil count, neutrophil/lymphocyte ratio (NLR), red cell distribution width (RDW), platelet count, and RDW/platelet ratio; surgical notes concerning resection status and inguinal hernia type; and demographic data. The patients included in the study were divided into two groups as those that had received a bowel resection and those that had not undergone this procedure.
\end{abstract}

Results: Of the 246 patients, 159 (65\%) were male and 87 (35\%) were female. The median age (interquartile range) was $71(66-78)$ years and $62(50-74)$ years in the resection $(n=23)$ and non-resection $(n=223)$ groups, respectively. There was a statistically significant difference between the two groups in terms of age $(p=0.004)$, neutrophil count $(0.001)$, NLR $(p=$ 0.000 ), and lymphocyte count (0.000). The multivariate analysis revealed that NLR (odds ratio $=1.113,95 \%$ confidence interval value: $1.055-1.175$, and $p=0.000$ ) was individually, independently and significantly associated with bowel resection.

Conclusion: Considering that it is possible to prevent the strangulation of a hernia in patients with IIH, urgent surgery is recommended for patients with an NLR of $>6.5$.

Keywords: Incarcerated inguinal hernia; bowel resection; inflammatory markers

Corresponding author*: Tezcan AKIN, Ankara City Hospital, Department of General Surgery, Ankara/TURKEY

E-mail: drtezcanakin@gmail.com

ORCID: $10.18663 /$ tjcl.906748

Recevied: 25.05.2021 accepted: 21/09/2021

Doi: $10.18663 / \mathrm{tjcl} .906748$ 


\section{öz}

Amaç: Barsak nekrozu olan inkarsere inguinal hernisi olan hastalarda inflamatuar belirteçlerin prediktif veya diagnostik değerini değerlendirmek.

Gereç ve Yöntemler: Çalışmaya Ankara Numune Eğitim ve Araştırma Hastanesi Acil Servisi'ne Ocak 2013 - Ocak 2018 tarihleri arasında inkarsere inguinal herni (iiH) tanısıyla ameliyat edilen 246 hasta dahil edildi. Elektronik hasta kayıtları, lenfosit sayısı, nötrofil sayısı, nötrofil / lenfosit oranı (NLO), kırmızı hücre dağılım genişliği (RDW), trombosit sayısı ve RDW / trombosit oranını; rezeksiyon durumu ve kasık fıtı̆ı tipiyle ilgili ameliyat notlarını ve demografik verileri elde etmek için tarandı. Çalışmaya dahil edilen hastalar barsak rezeksiyonu yapılanlar ve bu işlem yapılmayanlar olarak iki gruba ayrıldı.

Bulgular: 246 hastanın 159'u (\% 65) erkek, 87'si (\% 35) kadındı. Ortanca yaş (çeyrekler arası aralık) rezeksiyon ( $n=23)$ ve rezeksiyon olmayan $(n=223)$ gruplarda sırasıyla $71(66-78)$ yıl ve $62(50-74)$ yıldı. İki grup arasında yaş $(p=0.004)$, nötrofil sayısı (0.001), NLO ( $p=0.000)$ ve lenfosit sayısı $(p=0.000)$ açısından istatistiksel olarak anlamlı fark vardı. Çok değişkenli analiz, NLR'nin (olasılık oranı $=1.113, \% 95$ güven aralığı değeri: 1.055-1.175 ve $p=0.000$ ) ayrı ayrı, bağımsız ve önemli ölçüde bağırsak rezeksiyonu ile ilişkili olduğunu ortaya koydu.

Sonuç: iïH'li hastalarda fitığın strangülasyonunu önlemenin mümkün olduğu düşünüldüğünde, NLO> 6.5 olan hastalara acil cerrahi girişim önerilir.

Anahtar kelimeler: İnkarsere inguinal herni; barsak nekrozu; inflamatuar belirteçler

\section{Introduction}

Inguinal hernias are frequently encountered in current surgical practice. Levels of morbidity and mortality vary according to the resection status in emergency surgery. Although bowel resection is more common in femoral hernias than in other types of hernia, this procedure is undertaken in a considerable percentage $(15 \%)$ of all cases of incarcerated inguinal hernia (IIH) [1]. Studies have reported that bowel strangulation occurs in $57 \%$ of femoral hernias, with the morbidity and mortality being $33 \%$ and $7 \%$, respectively for patients that require resection due to this condition [2]. Strangulated inguinal hernia $(\mathrm{SIH})$ is the second most common cause of bowel obstruction and is among the first factors in the etiology of intestinal obstruction in patients without a history of laparotomy [3]. Early diagnosis is the most important factor to be considered in the progress from incarceration to strangulation, especially for the reduction of bowel resection [3]. However, there are very few studies in the literature related to inflammatory markers that predict early strangulation in emergency inguinal hernias [4]. Therefore, this study aimed to evaluate the predictive or diagnostic value of inflammatory markers in the presence of bowel necrosis in patients with $\mathrm{IH}$.

\section{Material and Methods}

\section{Study Design and Time period}

A total of 246 patients admitted to the Emergency Service of the General Surgery Clinic between January 2013 and January 2018 were included in the study. The study was approved by the local ethics committee (Approval Number: E-18-1996). The inclusion criteria were having the complaint of swelling in the groin, having a diagnosis of $\mathrm{IH}$ based on the findings of physical examination and $x$-ray imaging, and having undergone emergency inguinal hernia surgery.

\section{Study Setting}

The electronic patient records were retrospectively screened to obtain patients' demographic information; blood test results on lymphocyte count, neutrophil count, neutrophil/ lymphocyte ratio (NLR) red cell distribution width (RDW), platelet count, and RDW/platelet ratio; and surgical notes regarding resection status and type of inguinal hernia (Table 1). The results obtained from the laboratory values of the patients at the time of admission.

The patients included in the study were divided into two groups; those who had received a bowel resection (Group 1) and those who did not require this procedure (Group 2). The decision to undertake resection was taken based on the presence of necrosis in the bowel observed during surgery. 


\section{Data analysis}

Sample size was determined with power analysis calculated as $80 \%$ with $5 \%$ alfa error, and $20 \%$ beta error. All the statistical analyses were performed using SPSS version 17.0. The distribution of non-parametric numerical data was evaluated by the Kolmogorov-Smirnov test. The results for non-parametric continuous variables were given as median (interquartile range; IQR). The differences between the groups were analyzed using the Mann-Whitney $U$ test. The receiver operating characteristic (ROC) analysis was undertaken to calculate the cut-off values for age, neutrophil, NLR, and lymphocyte count. Multivariate logistic regression analysis was used to determine the significant variables that led to the decision for bowel resection. $P$ values of $<0.05$ were considered to be statistically significant.

\section{Results}

The sample consisted of 246 patients diagnosed with $\mathrm{IIH}$, of whom 159 (65\%) were male and 87 (35\%) were female. Inguinal hernia repair was performed on 23 patients with a bowel resection (Group 1) and 223 patients without a bowel resection (Group 2). The median ages and IQRs were71 (66-78) years and 62 (50-74) years in Groups 1 and 2, respectively.

The median (IQR) values for the variable parameters of the patients in Groups 1 and 2 were respectively as follows: leukocyte count (x103/mm3), 13.4 (9.4-15) and 10 (8-13.2); neutrophil count $(\times 103 / \mathrm{mm} 3), 11.1$ (8.5-12.8) and 7 (5.2-10.3); NLR 10.3 (6.4-17.1) and 3.8 (2.4-7.8); RDW, 14.3 (13.1-15.1) and 13.7(12.9-14.9); lymphocyte count ( $\mu \mathrm{l}), 900$ (700-1400) and 1700 (1200-2300); platelet count (×104/mm3), 26.2 (22.433.9) and 23.9(20.1-29.2), and RDW/PLT ratio, 0.05 (0.04-0.05) and 0.05 (0.04-0.06) (Table 1). Sixty-six patients (26\%) had a femoral hernia, and 171 (69\%) had an indirect inguinal hernia. Bowel resection was performed on 10 patients (15\%) with a femoral hernia and 13 patients $(0.076 \%)$ with an indirect inguinal hernia. Direct hernia was found in nine patients (5\%), none of whom required a bowel resection.

There was a statistically significant difference between Groups 1 and 2 in terms of age $(p=0.004)$, neutrophil count $(0.001)$, $\operatorname{NLR}(p=0.000)$, and lymphocyte count $(p=0.000)$. However, no statistically significant difference was found concerning leukocyte count $(p=0.065), \operatorname{RDW}(p=0.496)$, platelet count $(p=$ 0.056), and the RDW/PLT ratio $(p=0.093)$ (Table 1$)$

\begin{tabular}{|c|c|c|c|}
\hline Variables & $\begin{array}{c}\text { Group } 1 \\
n=23\end{array}$ & $\begin{array}{l}\text { Group } 2 \\
n=223\end{array}$ & $\begin{array}{c}\mathrm{p} \\
\text { value }\end{array}$ \\
\hline Age & $71(66-78)$ & $62(50-74)$ & $0.004^{*}$ \\
\hline Gender M/F (\%) & $14 / 9(60 / 40)$ & $145 / 78(65 / 35)$ & \\
\hline $\begin{array}{l}\text { Leukocyte count } \\
\left(\times 10^{3} / \mathrm{mm}^{3} 0.065\right)\end{array}$ & $13.4(9.4-15)$ & $10(8-13.2)$ & \\
\hline $\begin{array}{l}\text { Neutrophil count } \\
\left(\times 10^{3} / \mathrm{mm}^{3}\right)\end{array}$ & $11.1(8.5-12.8)$ & $7(5.2-10.3)$ & $0.001 *$ \\
\hline NLO & $10.3(6.4-17.1)$ & $3.8(2.4-7.8)$ & $0.000 *$ \\
\hline RDW & $14.3(13.1-15.1)$ & 13.7(12.9-14.9) & 0.496 \\
\hline Lymphocyte count & $900(700-1400)$ & $1700(1200-2300)$ & $0.000 *$ \\
\hline $\begin{array}{l}\text { Platelet count } \\
\left(\times 10^{4} / \mathrm{mm}^{3}\right)\end{array}$ & $26.2(22.4-33.9)$ & $23.9(20.1-29.2)$ & 0.056 \\
\hline RDW/PLT ratio & $0.05(0.04-0.05)$ & $0.05(0.04-0.06)$ & 0.093 \\
\hline $\begin{array}{l}\text { Hernia type } \\
\text { Femoral (\%) } \\
\text { Indirect (\%) } \\
\text { Direct (\%) }\end{array}$ & $\begin{array}{c}10(43) \\
13(47) \\
0\end{array}$ & $\begin{array}{l}56(25) \\
158(70) \\
9(5)\end{array}$ & $\begin{array}{l}>0.05 \\
>0.05 \\
>0.05\end{array}$ \\
\hline \multicolumn{4}{|c|}{$\begin{array}{l}\text { The data is expressed in median (interquartile range), RDW: Red cell } \\
\text { distribution width, RDW/PLT: Red cell distribution width/platelet ra- } \\
\text { tio, NLO: Neutrophil/lymphocyte ratio, }{ }^{*} \mathrm{p}<0.05 \text { was considered to } \\
\text { be statistically significant. (Mann Whitney u test, Fisher exact test). }\end{array}$} \\
\hline
\end{tabular}

In the ROC analysis, the area under the curve for age, neutrophil, NLR, and lymphocyte count was calculated as $0.679,0.719,0.802$, and 0.253 , respectively (Table 2). Based on these values, the cut-off values for age, neutrophil count, NLR, and lymphocyte count were determined as $66,10,6.5$, and 1300, respectively in patients in Group 1 (Figure 1).

\begin{tabular}{|c|c|c|c|}
\hline \multicolumn{4}{|c|}{$\begin{array}{l}\text { Table 2: Variables for the area under the curve in ROC analy- } \\
\text { sis on age, neutrophil count, NLO, and lymphocyte count. }\end{array}$} \\
\hline Variable & AUC & $95 \% \mathrm{Cl}$ & $p$ value \\
\hline Gender & 0.679 & $0.588-0.770$ & $0.005^{*}$ \\
\hline Neutrophil count & 0.719 & $0.619-0.819$ & $0.001^{*}$ \\
\hline NLO & 0.802 & $0.728-0.877$ & $0.000 *$ \\
\hline Lymphocyte count & 0.253 & $0.143-0.362$ & $0.000^{*}$ \\
\hline
\end{tabular}

The multivariate analysis revealed that NLR alone was independently and significantly associated with bowel resection (odds ratio $=1.113,95 \%$ confidence interval value $=$ 1.055-1.175, and $p=0.000$ ) (Table 3). NLR was $>6.5$ in all patients who developed strangulation, and there were no patients with radiologically normal strangulation. 


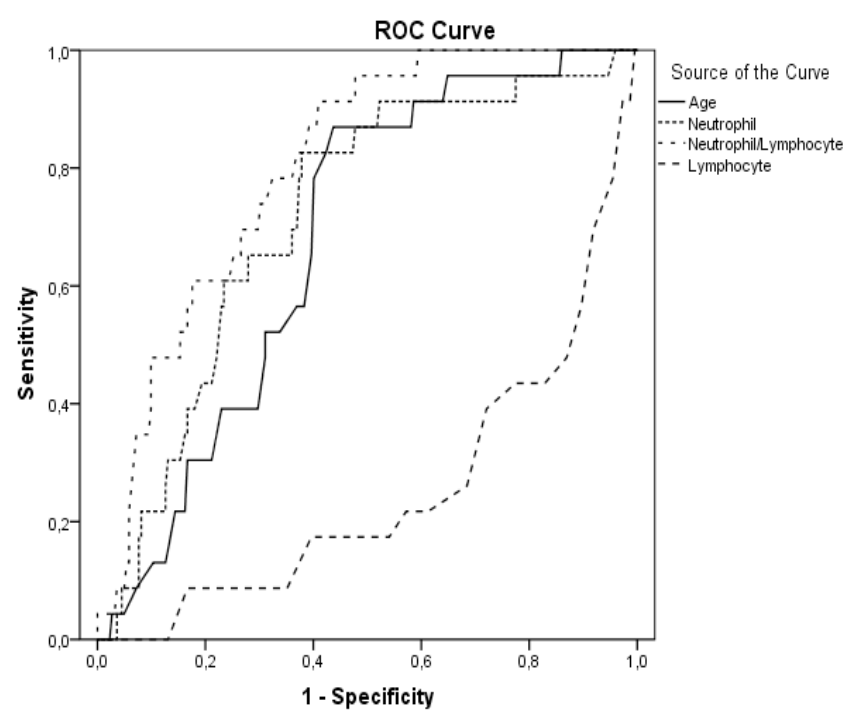

Figure 1: Results of the ROC analysis: Age, Neutrophil count, Neutrophil/Lymphocyte ratio, and Lymphocyte count.

Table 3: Multivariate regression analysis of patients with IIH
that had undergone a bowel resection.
$\begin{aligned} & \text { Variable } \\ & \text { NLO }>6.5\end{aligned}$
$\begin{aligned} & \text { OR } \\ & \text { IIH: Incarcerated inguinal hernia, OR: Odds ratio, Cl: Confidence interval, }\end{aligned}$
NLO: Neutrophil/lymphocyte ratio, *: Statistically significant (ROC analysis).

\section{Discussion}

Lower strength and increased intra-abdominal pressure in the abdominal muscles or fascia are the main causes of inguinal hernias. The relevant literature has emphasized that incarceration and strangulation are frequently seen, especially in indirect and femoral hernias. The rate of emergency surgery in these types of hernia has been reported to range from 5 to $15 \%$ [5]. $\mathrm{SIH}$ that develops particularly in indirect inguinal hernias but also in femoral hernias mostly constitute emergency cases. Especially, $\mathrm{SIH}$ involving indirect inguinal and femoral hernia presents a necessity for emergency surgery. In the literature, it has been stated that approximately $13-15 \%$ of IIH patients require a bowel resection $[1,5,6]$. In the current study, bowel resection was performed on approximately $10 \%$ of the cases, which is lower than the percentages reported in the literature.

Koizumi et al. [3] stated that in elderly patients, the factors leading to the requirement of a bowel resection include dementia, living alone, pain resistance, and delayed hospital admission. Xie et al [4] reported that the mean age, leukocyte count, and NLR were significantly higher in patients that underwent a bowel resection compared to the non-resection group. Similarly, de Guzmán C et al [8] showed that in geriatric patients, bowel resection was performed at a higher rate, as was also the case in the current study.

There are many studies in the literature confirming that inflammatory markers can be used in the diagnosis, prediction and differentiation of various diseases. It has also been reported that inflammatory markers may be useful when deciding on operative treatment [9]. For example, in recent years, the hs-CRP marker has become a topic of intensive research to detect the severity of heart failure and preeclampsia $[10,11]$. Recently, the efficacy of inflammatory markers in the differential diagnosis of complicated and uncomplicated acute diverticulitis has also been investigated [12].

In particular, for patients with $\mathrm{SIH}$, early diagnosis is extremely important for the prevention of morbidities, such as perforation, and reducing the risk of bowel necrosis [1, 13]. Early diagnosis may prevent the development of the SIH by providing that such patients can be manually rehabilitated during the $\mathrm{IH}$ period. Since acute abdominal findings may develop in strangulated inguinal hernias, physical examination findings are important in these patients, and serial abdominal examinations after manual hernia reduction should not be neglected. Neutrophil is an inflammatory response that suppresses lymphocytes. NLR has been shown to be a good predictor, especially for the diagnosis of gangrenous and perforated acute appendicitis in elderly patients [14-17]. Similarly, it has been shown that an NLR value greater than 6.35 can be used to evaluate acute cholecystitis [18]. In a study by Zhou et al [19], SIH was found to be associated with neutrophil count and NLR by univariate analysis, and with NLR by multivariate analysis. In the same study, the sensitivity and specificity were reported to be $75 \%$ and $65.9 \%$, respectively for NLR and $68.9 \%$ and $71.1 \%$, respectively for neutrophil count.

In the literature, a multivariate analysis showed that NLR $>6.5$ was associated with $\mathrm{SIH}$ patients requiring bowel resection [19]. We revealed that NLR was a good predictor for necrosis in incarcerated inguinal hernia. We showed that mean age, neutrophil, lymphocyte count, and NLR was statistically significantly high in the bowel resection group. We analyzed this parameters with ROC analysis for determining the cut off values. In our study, NLR and the number of neutrophils were found to be statistically significantly higher in $\mathrm{SIH}$ patients in the resection group. These similar results indicate that this ratio can predict the necessity of resection especially in patients with $\mathrm{SIH}$. Similarly, NLR appeared to be the best inflammatory marker for the area under the curve in this study. 
It has been shown that when infectious conditions, such as appendicitis are present, neutrophilic granulocytes increase but lymphocytes decrease $[20,21]$. Consistent with this finding in the literature, in our study, the number of lymphocytes was found to be statistically significantly lower in patients that had undergone a bowel resection than those in the non-resection group.

In the literature, it has been reported that $20.8-38.5 \%$ of bowel resections are performed on patients with femoral hernias [7, 22]. In our study, 10 (43\%) of 23 patients who underwent a resection had femoral hernia.

The limitations of this study are the retrospective design and patients being grouped only based on patients' surgical records.

\section{Conclusion}

Considering that it is possible to prevent strangulation of hernia in patients with $\mathrm{IIH}$, urgent surgery is recommended for patients with an NLR of $>6.5$.

\section{Declaration of conflict of interest}

The authors received no financial support for the research and/or authorship of this article. There is no conflict of interest

\section{References}

1. Kurt N, Oncel M, Ozkan Z, Bingul S. Risk and outcome of bowel resection in patients with incarcerated groin hernias: retrospective study. World J Surg 2003; 27: 741-3.

2. Alvarez JP, Baldonedo RF, Bear IG, Solis J, Alvarez P, Jorge J.. Emergency hernia repairs in elderly patients. Int Surg 2003; 88: 231-7.

3. Koizumi M, Sata N, Kaneda $\mathrm{Y}$ et al. Optimal timeline for emergency surgery in patients with strangulated groin hernias. Hernia 2014; 18: 845-8.

4. Xie X, Feng S, Tang Z, Chen L, Huang Y, Yang X. Neutrophil-toLymphocyte Ratio Predicts the Severity of Incarcerated Groin Hernia. Med Sci Monit 2017; 23: 5558-63.

5. Kulah B, Kulacoglu IH, Oruc MT et al. Presentation and outcome of incarcerated external hernias in adults. Am J Surg 2001; 181: 101-4.

6. Alvarez J, Baldonedo R, Bear I, Solis J, Alvarez P, Jorge J. Incarcerated groin hernias in adults: presentation and outcome. Hernia 2004; 8: 121-6.

7. Ge B-J, Huang Q, Liu L-M, Bian H-P, Fan Y-Z. Risk factors for bowel resection and outcome in patients with incarcerated groin hernias. Hernia 2010; 14: 259-64.

8. de Guzmán CA-R, Picazo-Yeste J, Tenías-Burillo JM, MorenoSanz C. Improved outcomes of incarcerated femoral hernia: a multivariate analysis of predictive factors of bowel ischemia and potential impact on postoperative complications. Am J Surg 2013; 205: 188-93.
9. Beecher SM, Hogan J, O'Leary DP, McLaughlin R. An appraisal of inflammatory markers in distinguishing acute uncomplicated and complicated appendicitis. Dig Surg 2016; 33: 177-81.

10. Pearson M, Mungovan S, Smart N. Effect of aerobic and resistance training on inflammatory markers in heart failure patients: systematic review and meta-analysis. Heart Fail Rev 2018: 1-15.

11. Jannesari R, Kazemi E. Level of High Sensitive C-reactive Protein and Procalcitonin in Pregnant Women with Mild and Severe Preeclampsia. Adv Biomed Res 2017; 6.

12. Hogan J, Sehgal R, Murphy D, O'leary P, Coffey JC. Do Inflammatory Indices Play a Role in Distinguishing between Uncomplicated and Complicated Diverticulitis? Dig Surg. 2017; 34: 7-11.

13. Andrews N. Presentation and outcome of strangulated external hernia in a district general hospital. Br J Surg 1981; 68: 329-32.

14. Goodman DA, Goodman CB,MonkJS. Use of the neutrophil:lymphocyte ratio in the diagnosis of appendicitis. Am Surg 1995; 61:257-9.

15. Ishizuka M, Shimizu T, Kubota K. Neutrophil-to-lymphocyte ratio has a close association with gangrenous appendicitis in patients undergoing appendectomy. Int Surg 2013; 97: 299-304.

16. Jung SK, Rhee DY, Lee WJ, Woo SH, Seol SH, et al. Neutrophilto-lymphocyte count ratio is associated with perforated appendicitis in elderly patients of emergency department. Aging Clin Exp Res 2017; 29: 529-36.

17. ShimizuT, Ishizuka M, Kubota K. A lower neutrophil to lymphocyte ratio is closely associated with catarrhal appendicitis versus severe appendicitis. Surg Today 2016; 46: 84-9.

18. Lee SK, Lee SC, Park JW, Kim S-J. The utility of the preoperative neutrophil-to-lymphocyte ratio in predicting severe cholecystitis: a retrospective cohort study. BMC Surg. 2014; 14: 100.

19. Zhou H, Ruan X, Shao X, Huang X, Fang G, Zheng X. Clinical value of the neutrophil/lymphocyte ratio in diagnosing adult strangulated inguinal hernia. Int J Surg 2016; 36: 76-80.

20. Mohammed AA, Daghman NA, Aboud SM, Oshibi HO. The diagnostic value of $C$-reactive protein, white blood cell count and neutrophil percentage in childhood appendicitis. Saudi Med J 2004; 25: 1212-5.

21. Nathan C. Neutrophils and immunity: challenges and opportunities. Nat Rev Immunol. 2006; 6: 173.

22. Suppiah A, Gatt M, Barandiaran J, Heng M, Perry E. Outcomes of emergency and elective femoral hernia surgery in four district general hospitals: a 4-year study. Hernia 2007; 11: 509-12. 